\title{
High resolution modelling of the North Icelandic Irminger Current (NIIC)
}

\author{
K. Logemann ${ }^{1, *}$ and I. Harms ${ }^{1}$ \\ ${ }^{1}$ Centre for Marine and Climate Research, Institute for Oceanography, University of Hamburg, Bundesstraße 53, 20146 \\ Hamburg, Germany \\ *now at: University of Iceland, Askja, Sturlugata 7, 101 Reykjavik, Iceland
}

Received: 14 June 2006 - Published in Ocean Sci. Discuss.: 1 August 2006

Revised: 31 October 2006 - Accepted: 28 November 2006 - Published: 11 December 2006

\begin{abstract}
The northward inflow of Atlantic Water through Denmark Strait - the North Icelandic Irminger Current (NIIC) - is simulated with a numerical model of the North Atlantic and Arctic Ocean. The model uses the technique of adaptive grid refinement which allows a high spatial resolution ( $1 \mathrm{~km}$ horizontal, $10 \mathrm{~m}$ vertical) around Iceland. The model is used to assess time and space variability of volume and heat fluxes for the years 1997-2003. Passive tracers are applied to study origin and composition of NIIC water masses.

The NIIC originates from two sources: the Irminger Current, flowing as part of the sub-polar gyre in $100-500 \mathrm{~m}$ depth along the Reykjanes Ridge and the shallow Icelandic coastal current, flowing north-westward on the south-west Icelandic shelf. The ratio of volume flux between the deep and shallow branch is around 2:1. The NIIC continues as a warm and saline branch northward through Denmark Strait where it entrains large amounts of polar water due to the collision with the southward flowing East Greenland Current. After passing Denmark Strait, the NIIC follows the coast line eastward being an important heat source for north Icelandic waters.
\end{abstract}

At least $60 \%$ of the temporal temperature variability of north Icelandic waters is caused by the NIIC. The NIIC volume and heat transport is highly variable and depends strongly on the wind field north-east of Denmark Strait. Daily means can change from $1 \mathrm{~Sv}$ eastward to $2 \mathrm{~Sv}$ westward within a few days. Highest monthly mean transport rates occur in summer when winds from north are weak, whereas the volume flux is reduced by around $50 \%$ in winter. Summer heat flux rates can be even three times higher than in winter. The simulation also shows variability on the interannual scale. In particular weak winds from north during winter 2002/2003 combined with mild weather conditions south of

Correspondence to: I. Harms

(harms@ifm.uni-hamburg.de)
Iceland led to anomalous high NIIC volume $(+40 \%)$ and heat flux $(+60 \%)$ rates. In this period, simulated north Icelandic water temperatures are at least $0.5 \mathrm{~K}$ warmer than average.

\section{Introduction}

The transport of warm and saline Atlantic water masses (AW) northward across the Greenland-Iceland-Scotland ridge is an essential component of the Atlantic Meridional Overturning Circulation (AMOC). Water mass characteristics of the sub-polar North Atlantic, the Arctic ice cover and to a large extent the climate of North-western Europe strongly depend on the intensity of the AMOC. The inflow of AW into the Nordic Seas occurs via three branches: between Greenland and Iceland through Denmark Strait (1 Sv), between Iceland and the Faeroe Islands ( $3.3 \mathrm{~Sv}$ ) and through the Faeroe-Shetland Channel (3.7 Sv) (Hansen and Østerhus, 2000).

This study investigates in more detail the transport west of Iceland through Denmark Strait which is the smallest and the most variable flux of all three passages. In the frame of the EU project METACOD ${ }^{1}$, a high resolution 3-D hydrodynamic model is set up to trace pathways and fate of cod eggs that are spawned in south Icelandic waters (Brickman et al., 2006). The egg drift usually follows an anti-cyclonic coastal circulation from the south coast of Iceland, north-westward through Denmark Strait and northward up to the nursery areas along the north coast of Iceland. The drift is part of the North Icelandic Irminger Current (NIIC) that is responsible for the transport of warm and saline Atlantic Waters onto the north Icelandic shelf (Fig. 1). Although this northward transport is small compared to the other through-flows, convection processes in the Iceland Sea and the ecosystem on the north

\footnotetext{
${ }^{1}$ METACOD - role of sub-stock structure in the maintenance of cod metapopulations
} 


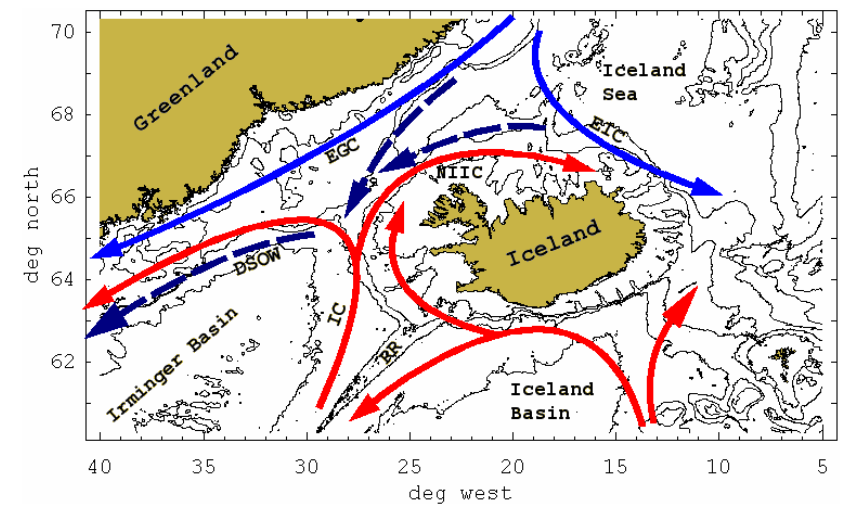

Fig. 1. Bathymetry around Iceland in depth intervals of 200, 500, 1000, 2000 and $3000 \mathrm{~m}$. Red arrows: Atlantic Water (AW), blue arrows: Polar and Arctic Waters (PW) and dashed blue arrows: Denmark Strait Overflow Water (DSOW). Other abbreviations are: EGC - East Greenland Current, EIC - East Icelandic Current, IC Irminger Current, NIIC - North Icelandic Irminger Current, RR Reykjanes Ridge.

Icelandic Shelf depend on the import of heat, salt and nutrients by the NIIC (Hansen and Østerhus, 2000; Jónsson and Valdimarsson, 2005).

Estimations of the NIIC's volume flux are mostly in the range of $1 \mathrm{~Sv}$ (Jónsson and Briem, 2003; Worthington, 1970) but can vary between $0.6 \mathrm{~Sv}$ (Stefánsson, 1962) and $2 \mathrm{~Sv}$ (Dietrich et al., 1975). Kristmannsson $(1989,1998)$ emphasizes a strong variability with transport rates between $0-2.8 \mathrm{~Sv}$. The newest estimation by Jónsson and Valdimarsson (2005) gives $1.1 \mathrm{~Sv}(66 \% \mathrm{AW})$ and latest model results show a NIIC volume transport of $0.5 \mathrm{~Sv}$ (Nilsen et al., 2003).

\section{Model description}

The 3-dimensional circulation model CODE (Cartesian coordinates Ocean model with three-Dimensional adaptive mesh refinement and primitive Equations, Logemann, 2006) was applied. The model uses the primitive equations in a static adaptive finite difference grid, on geopotential vertical levels. The main difference to other adaptive solvers on similar grids, e.g. the model of Khokhlov (1998) or GERRIS (Popinet, 2003), is the avoidance of a (multilevel) Poisson solver when computing the pressure. CODE uses the hydrostatic pressure approximation, i.e. it neglects accelerations caused by vertical pressure gradients which are part of the Poisson equation. The model's treatment of the primitive equations is based on HAMSOM/VOM (Backhaus, 1985) which has been frequently applied to the north-eastern North Atlantic (e.g. Harms et al., 1999a, b, 2000; Logemann et al., 2004). A recent development of HAMSOM/VOM also includes adaptive mesh refinement (Harms et al., 2003). However, its refinement is restricted to the vertical and it uses a different organisation of grid cells.
The grid cell organisation in CODE mainly follows the tree algorithm of Khokhlov (1998) that determines the spatial discretisation and grid cell organisation (Fig. 2). The pairs of numbers within the cells (left panel) denote the level of horizontal (first number) and vertical (second number) refinement. A cell with the pair $(n, m)$ has a size of $\Delta x=\Delta x_{0} \times 2^{-n}$ in $\mathrm{x}$-direction and $\Delta z=\Delta z_{0} \times 2^{-m}$ in z-direction. The level of horizontal refinement $n$ does not vary along the z-axis ensuring well defined water columns for hydrostatic pressure computation. The large basic cells of the size $\Delta x_{0}$ and $\Delta z_{0}$, with the pair $(0,0)$ (Fig. 2, right panel), are located at the top. Some of these cells were assigned to "children" which are located one row below. These are cells which are refined by one level and which take up the volume of their "parent cell" together. First the refinement is performed horizontally. Only after the maximum horizontal level is reached, the vertical refinement starts. Only the "leaves" (marked red in Fig. 2), i.e. the cells without children, are directly used for solving the model equations. The parent cells just obtain the mean properties of their children at each time step.

The sea surface elevation $\zeta$ is determined by integrating vertically the equation of continuity. The hydrostatic pressure $p$ at the depth $z$ results from vertical integration of the water density $\rho$ multiplied with the gravitational acceleration $g$ from the depth $z$ up to the sea surface. Therefore the grid cells have to form well defined water columns (integration paths) and a variation of the horizontal resolution within a water column is omitted. Compared to GERRIS this sets up additional restrictions to the adaptive mesh refinement's spatial structure. On the other hand, the avoidance of solving the Poisson equation saves much computing time. The horizontal pressure gradient (along the $\mathrm{x}$-axis) is computed with

$\frac{\partial p}{\partial x}=\rho_{0} g \frac{\partial \zeta}{\partial x}+g \int_{z}^{\zeta} \frac{\partial \rho}{\partial x} d z^{\prime}$,

where $\rho_{0}=$ const. is the fluid's mean density. This way the spurious horizontal pressure gradient caused by computing $\frac{\partial p}{\partial x}=\frac{\partial}{\partial x}\left(\int_{z}^{\zeta} \rho g d z^{\prime}\right)$ between two differently resolved water columns are removed. The density gradients are computed with

$$
\frac{\partial \rho}{\partial x}=f\left(\frac{\partial T}{\partial x}, \frac{\partial S}{\partial x}, p\right),
$$

where $f$ is a linear function of the temperature $(T)$ and salinity $(S)$ gradient, and the pressure $p$ obtained by a least squares fit to data produced with the UNESCO equation of state (Millero et al., 1980). The remaining spurious horizontal density gradient between two cells of different thickness (caused by spurious temperature and salinity gradients) is avoided by jumping to the next lower level of vertical refinement if necessary (Fig. 3).

Horizontal and vertical turbulence is parameterised by algorithms following Smagorinsky (1963) and Kochergin 

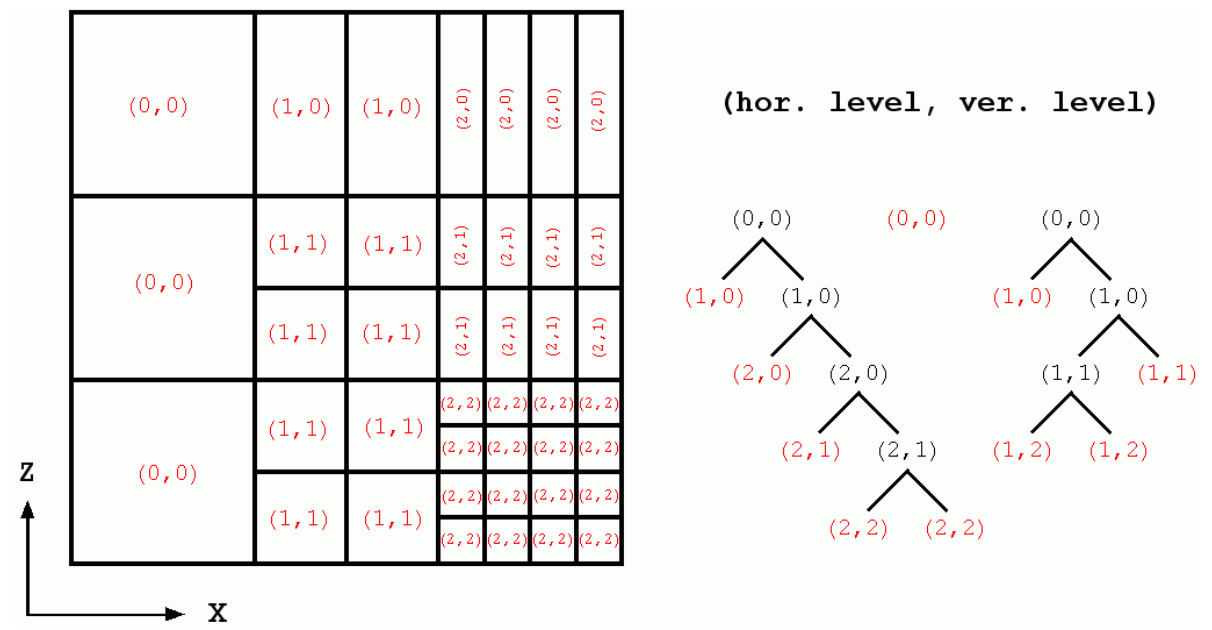

Fig. 2. Scheme of the computational mesh consisting of differently sized cells (left) and scheme of the mesh producing tree algorithm (right). See text for details.

(Kochergin, 1987). The Smagorinsky constant is determined through optimisation of model trajectories along the trajectories of (WOCE) surface drifters drogued at $15 \mathrm{~m}$ depth (Valdimarsson and Malmberg, 1999). The horizontal diffusion, parametrised in this way, is equally applied for diffusion of momentum and scalar variables $(T, S)$. Threedimensional advection of momentum and scalar tracers $(T$, $S$ ) is realized by an FTCS approach (forward in time, centred in space) using the van Leer flux limiter function (van Leer, 1979).

The model domain comprises the North Atlantic and Arctic Ocean (Fig. 4a). The equator and the Bering Strait are treated as closed boundaries. The base matrix resolution is $320 \mathrm{~m}$ in the vertical and between $75 \mathrm{~km}$ and $150 \mathrm{~km}$ in the horizontal domain (higher in polar and sub-polar regions). Close to the sea surface the vertical resolution is increased to $10 \mathrm{~m}$ (Fig. 4c). Within the north-east North Atlantic and the Nordic Seas adaptive mesh refinement increases the resolution when approaching Icelandic waters. The maximum resolution is $1.2 \mathrm{~km}$ horizontal and $10 \mathrm{~m}$ vertical over the entire water column (Fig. 4b, c). The model is eddy resolving over much of Iceland's shelf waters. The topography is based on the IBCAO data set (Jakobsson et al., 2000) for polar and sub-polar regions and on the ETOPO-5 data set (Bamber et al., 1997) for the Atlantic/North Atlantic, with a blending technique in the transition zone.

For spin up, CODE was integrated for 10 years on the coarse base grid and for three more years with full resolution. The model is initialised with climatological temperature and salinity data from the PHC (Polar science center Hydrographic Climatology) world ocean data set (Steele et al., 2001) and forced with ECMWF atmospheric reanalysis data that describes a cyclic stationary, climatological year (Ocean Model Intercomparison Project (OMIP) dataset, Röske, 2006). Ocean temperature and salinity fields were

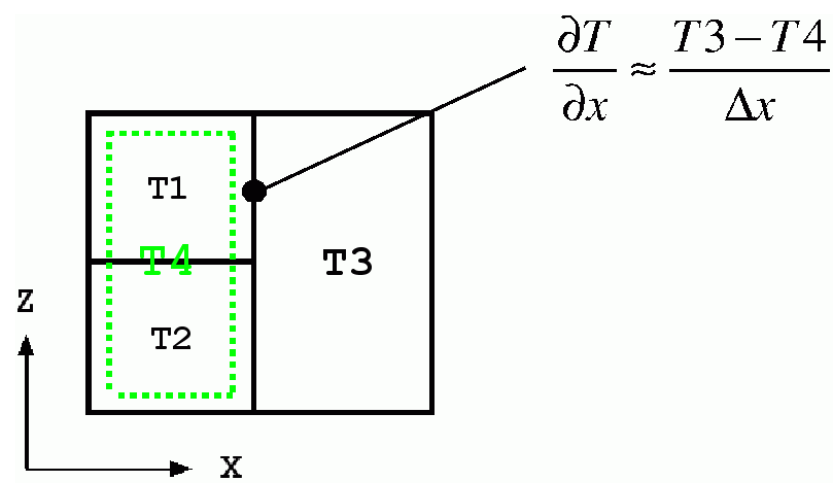

Fig. 3. The computational scheme for the horizontal gradient of temperature or salinity between grid cells of different thickness. Consider the horizontal homogeneous but stratified case. I.e. $0.5 \times(\mathrm{T} 1+\mathrm{T} 2)=\mathrm{T} 3$ and $\mathrm{T} 1 \neq \mathrm{T} 2$. In order to avoid the spurious gradient between $\mathrm{T} 1$ and $\mathrm{T} 3$ the gradient is computed between $\mathrm{T} 3$ and the parent cell of $\mathrm{T} 1$, the cell $\mathrm{T} 4=0.5 \times(\mathrm{T} 1+\mathrm{T} 2)$. Hence the horizontal gradient is zero.

restored to monthly $\mathrm{PHC}$ fields using a time constant of 30 days. Following the climatological spin up period, the model system is integrated for 8 years (1996-2003), using 6 hourly NCEP/NCAR data for wind stress and direction, air temperature, cloud cover, humidity and precipitation (Kalnay et al., 1996). Runoff data from 11 Icelandic rivers, provided by the Hydrological Service of the Icelandic National Energy Authority, is applied as freshwater volume flux into the model domain (National Energy Authority, 2003). The model results are analysed from 1997 on. 


\section{Model results}

\subsection{Large scale overview}

The simulated circulation in the North Atlantic is qualitatively in good agreement with the surface flow deduced from buoy drift, published by Jakobsen et al. (2003). The simulated Irminger Current structure east and west of the Reykjanes Ridge resembles the circulation schemes given by $\mathrm{Di}$ etrich et al. (1975), Bersch (1995) and van Aken and Becker (1996). Also the circulation pattern over the west-Icelandic shelf does not contradict to the observations by Valdimarsson and Malmberg (1999).

Quantitatively, the model slightly underestimates volume fluxes across the Iceland-Scotland ridge (Table 1) compared with observational based values given by Hansen and Østerhus (2000). The simulated amount of inflowing AW through the Greenland-Iceland section $(0.3 \mathrm{~Sv})$ is significantly lower than their estimation (1 Sv), which has, on the other hand, an uncertainty of around $1 \mathrm{~Sv}$ (Hansen and Østerhus, 2000). However, recent current meter records reveal an AW inflow of $0.75 \pm 0.15 \mathrm{~Sv}$ (Jónsson and Valdimarsson, 2005) during the late 1990s and point towards a possible model underestimation.

The origin of the NIIC is the cyclonic sub-polar gyre in the Iceland and Irminger basin (see Fig. 1). To the southwest of the island, the broad westward flow breaks into an in-shore current that follows the Icelandic coast and an offshore branch that follows the Reykjanes ridge, crosses it further south-west and continues as part of the Irminger Current towards Denmark Strait (Fig. 5). Large parts of the Irminger Current re-circulate south-west of Denmark Strait and only a small part forms together with the coastal flow the NIIC. Whereas the off-shore branch is of AW origin $(\mathrm{S}>35.0)$ and reaches down to $500 \mathrm{~m}$, the in-shore branch appears as a shallow coastal current that entrains freshwater from land runoff $(\mathrm{S}<35.0)$.

The high resolution flow field in Fig. 5 shows a clockwise circulation around Iceland with the warm north-westward flowing branch of the Irminger Current as the most prominent feature. The continuation of this current, the NIIC, flows north-eastward through Denmark Strait and shares the narrow passage with cold, less saline southward flowing polar and arctic water masses (PW) of the East Greenland Current. The collision of warm, saline and cold, fresh water masses results in a distinct front between both currents. The NIIC continues further eastward and reaches the north coast of Iceland where it influences significantly the shelf hydrography. In this area predominant parts of the flow are topographically steered. The core of the NIIC lies in approx. $100 \mathrm{~m}$ depth just over the $150 \mathrm{~m}$ depth contour which is in good agreement with observations (Jónsson and Valdimarsson, 2005). Near surface waters follow closely the shore line along the north coast and flush even smaller fjords up to their inner parts with relative warm and salty AW.

\subsection{Spatial variability of the NIIC}

In order to assess the spatial variability of the NIIC on its way around Iceland, 15 model sections were defined west and north of the island (Fig. 6). The following analysis is based on the mean flow field from the period 1997-2003.

Table 2 shows, that volume fluxes of the in-shore branch (sections 1a, 2a, 3a) are significantly lower than those from the off-shore branch (sections $1 b, 2 b, 3 b$ ). Both branches merge into section 4 , that can be regarded as the NIIC origin. A striking feature is that from section 4 on, the transport rates $(0.9 \mathrm{~Sv})$ are reduced abruptly by almost $50 \%$ down to 0.4 and $0.5 \mathrm{~Sv}$ at sections 5 and 6 , respectively. Further downstream, the volume flux recovers slightly and section 7 yields again a transport of $0.6 \mathrm{~Sv}$. However, in spite of this recovery, the simulated total transport through section 7 remains below estimations by Jónsson and Valdimarsson (2005) who give 1.1 Sv transport (AW fraction 66\%) between 1994 and 2000 through Hornbanki section that is equivalent to our section 7 .

The spatial variability of the volume flux is also reflected in the heat flux rates, presented in the last column in Table 2 (note that all heat flux rates presented in this paper are calculated relative to $0^{\circ} \mathrm{C}$ and present thus a quasi-heat flux or temperature flux). The contribution of the in-shore pathway to the total heat flux through section 4 (18 TW) is approx. 15$20 \%$. The major part of the heat advection by the NIIC is thus made up by AW from the Irminger Current (sections $1 \mathrm{~b}$, $2 \mathrm{~b}$ and $3 \mathrm{~b}$ ). As with the volume flux, the heat transport decreases significantly after section 4 but recovers and stabilizes on the following sections downstream. The mean temperature, however, drops more or less continuously whereas the mean salinity remains stable from section 6 on and even increases slightly towards the last two sections.

\subsection{Temporal variability of the NIIC}

\subsubsection{High frequent variability (days-months)}

The model indicates, that in-shore or shelf transport rates (sections 1a, 2a and 3a) are highly variable in time. Daily mean values and corresponding standard deviations at these sections are similar in magnitude $(0.25 \mathrm{~Sv}, 0.16 \mathrm{~Sv}$ and $0.17 \mathrm{~Sv}$, respectively) and maximum transport rates of $1 \mathrm{~Sv}$ may occur in both directions. Strong, mainly wind induced variability is also simulated further downstream at section 7 , where values for the volume flux can range from e.g. eastward $0.84 \mathrm{~Sv}$ (31 January 2002) to westward $1.91 \mathrm{~Sv}$ (3 February 2002) (Fig. 7), the latter value being caused by a strong atmospheric cyclone east of Iceland at that time. The standard deviation for daily mean volume fluxes is $0.32 \mathrm{~Sv}$. Similar variability is simulated for the temperature and salinity distribution. At section 7, the simulated daily means give standard deviations of $0.29 \mathrm{~K}$ and 0.034 psu.

The red curve in Fig. 7 shows volume fluxes derived from current measurements along section 7 (Jónsson and 

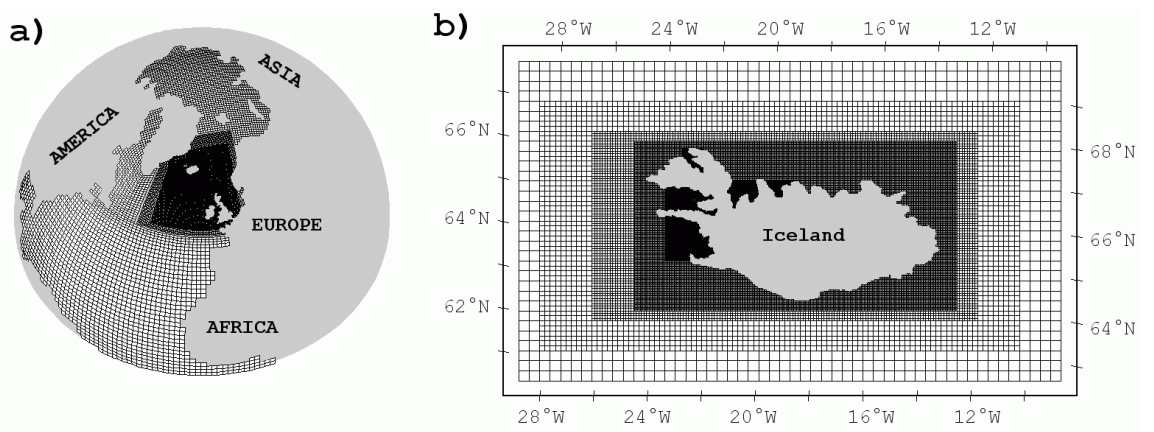

C)

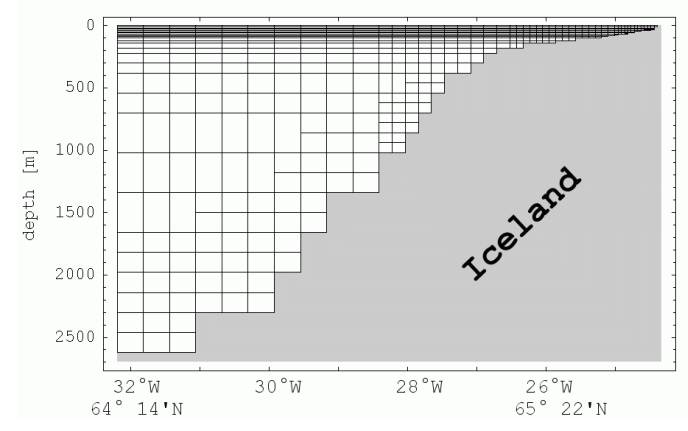

Fig. 4. The adapted model grid: (a) whole model domain including the North Atlantic, the Nordic Seas and the Arctic Ocean, (b) high resolution grid around Iceland, (c) section west of Iceland.

Table 1. Comparison between simulated and observed volume fluxes in the overflow region.

\begin{tabular}{lcc}
\hline overflow section & model & Hansen and Østerhus (2000) \\
\hline Iceland-Scotland northward inflow of AW (Sv) & 6.7 & 7 \\
Iceland-Scotland overflow (Sv) & 2.9 & 3 \\
Greenland-Iceland northward inflow of AW (Sv) & 0.3 & 1 \\
Greenland-Iceland overflow (Sv) & 2.4 & 3 \\
\hline
\end{tabular}

Valdimarsson, 2005). Between May 1997 and June 2002 the mean volume flux of this time series is $0.83 \mathrm{~Sv}$ with a standard deviation of monthly means of $0.20 \mathrm{~Sv}$. For the same period, the model shows a mean value of $0.57 \mathrm{~Sv}$ with a standard deviation of monthly means of $0.18 \mathrm{~Sv}$. I.e. in spite of different mean values the relative variances of the modelled and observation-based time series are almost the same $(6 \%$ and $5 \%$, respectively). The correlation between both time series is 0.62 , a rather high value when considering that the red curve describes the AW volume flux only (AW fraction of $66 \%$ ), whereas the black curve describes the total flux.

The mean heat flux (relative to $0^{\circ} \mathrm{C}$ ) through section 7 is $9 \mathrm{TW}$ with a standard deviation of $0.5 \mathrm{TW}$, whereas Jónsson and Valdimarsson (2005), mainly as a consequence of their higher volume flux computation, estimate $19 \pm 4$ TW for the mean value. We compare the contributions of volume flux $(M)$ and temperature $(T)$ to the heat flux variability by com- paring the sums

$$
S_{1}=\sum_{\text {day }}\left|M_{\text {day }}-\bar{M}\right| \bar{T} \rho c_{p}
$$

and

$S_{2}=\sum_{\text {day }}\left|T_{\text {day }}-\bar{T}\right| \bar{M} \rho c_{p}$,

where $M_{\text {day }}, T_{\text {day }}$ denote daily values, $\bar{M}, \bar{T}$ the mean values, $\rho$ the density of sea water and $c_{p}$ its constant pressure heat capacity. Hence, $S_{1}$ is a measure of the heat flux variability caused by changes of volume flux, whereas $S_{2}$ measures the heat flux variability caused by temperature changes.

We conclude that the volume flux is responsible for $68 \%$ of the heat flux variability on section 7 and only $32 \%$ is due to temperature variability (seasonal signal included). Note, that the $S_{1} / S_{2}$ ratio depends on the volume flux relative variance rather than on its mean value. The damping of model variability ( $T, S$ and baroclinic currents) caused by the applied 


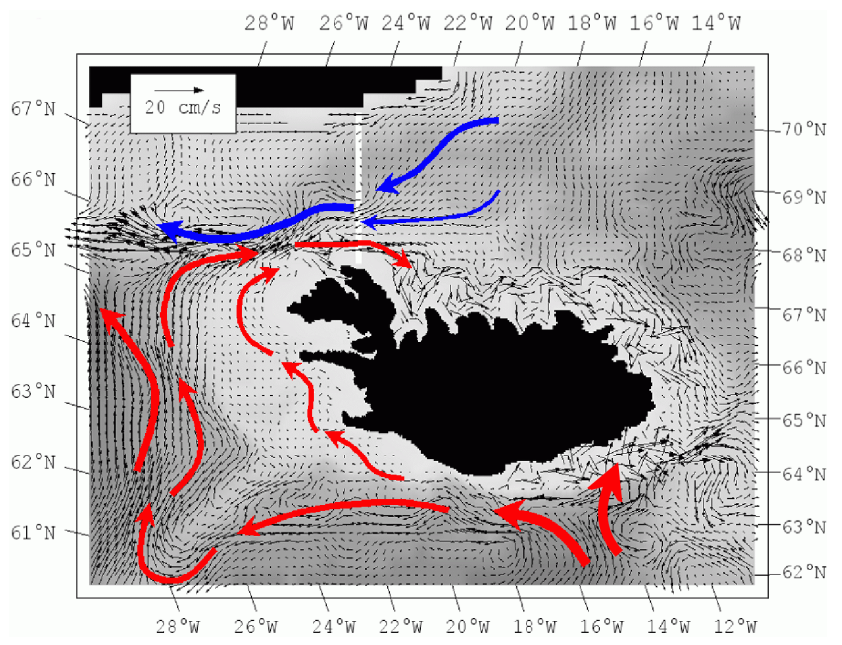

Fig. 5. Simulated mean velocity for the period $1997-2003$ in $100 \mathrm{~m}$ depth. Scale refers to black arrows; coloured arrows are schematic. The greyscale illustrates topography.

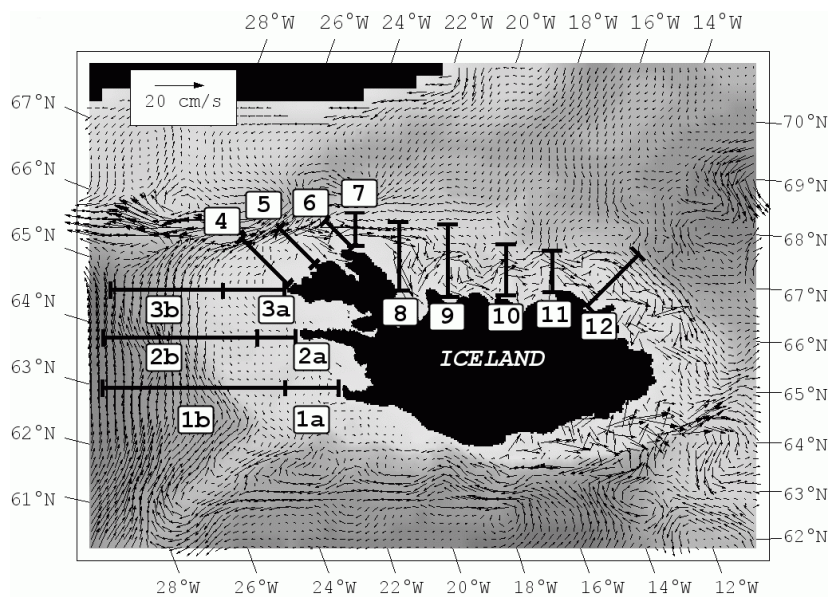

Fig. 6. Simulated mean velocity field at $100 \mathrm{~m}$ depth for the period 1997-2003 and positions of 15 analysed model sections (Table 2). The greyscale illustrates topography.

temperature and salinity restoring is below $10 \%$ for periods shorter than 100 days (Fig. 8). We therefore conclude that the impact of the restoring procedure on simulated high frequent variability is insignificant.

\subsubsection{Seasonal variability}

The analysis of the yearly cycle of NIIC transport rates and heat fluxes on section 7 together with mean temperatures on the north Icelandic shelf, averaged for 1997-2003, shows a pronounced seasonal signal (Fig. 9). All three variables show maximum values in spring/summer and minimum values in autumn/winter. The largest amplitude is visible for the heat flux curve where the summer value is more than three times higher than the winter value. This strong seasonality is due
Table 2. Simulated volume flux, mean temperature, salinity and quasi-heat flux (relative to $0^{\circ} \mathrm{C}$ ) averaged over the years 1997-2003 at 15 model sections (see Fig. 6).

\begin{tabular}{lllll}
\hline section & $\begin{array}{l}\text { volume } \\
\text { flux }(\mathrm{Sv})\end{array}$ & $\mathrm{T}\left({ }^{\circ} \mathrm{C}\right)$ & $\mathrm{S}(\mathrm{psu})$ & $\begin{array}{l}\text { heat } \\
\text { flux (TW) }\end{array}$ \\
\hline $1 \mathrm{a}$ & 0.1 & 7.41 & 34.93 & 3 \\
$\mathrm{2a}$ & 0.2 & 6.96 & 35.00 & 5 \\
$3 \mathrm{a}$ & 0.2 & 5.87 & 34.90 & 5 \\
& & & & \\
$1 \mathrm{~b}$ & 12 & 6.21 & 35.06 & 300 \\
$2 \mathrm{~b}$ & 11 & 6.03 & 35.05 & 270 \\
$3 \mathrm{~b}$ & 8 & 5.78 & 35.03 & 190 \\
& & & & \\
4 & 0.9 & 5.04 & 34.88 & 18 \\
5 & 0.4 & 4.50 & 34.72 & 7 \\
6 & 0.5 & 3.63 & 34.60 & 8 \\
7 & 0.6 & 3.43 & 34.61 & 9 \\
8 & 0.6 & 3.54 & 34.48 & 9 \\
9 & 0.7 & 3.37 & 34.63 & 10 \\
10 & 0.5 & 3.38 & 34.66 & 8 \\
11 & 0.7 & 2.51 & 34.72 & 8 \\
12 & 0.9 & 1.68 & 34.71 & 8 \\
\hline
\end{tabular}

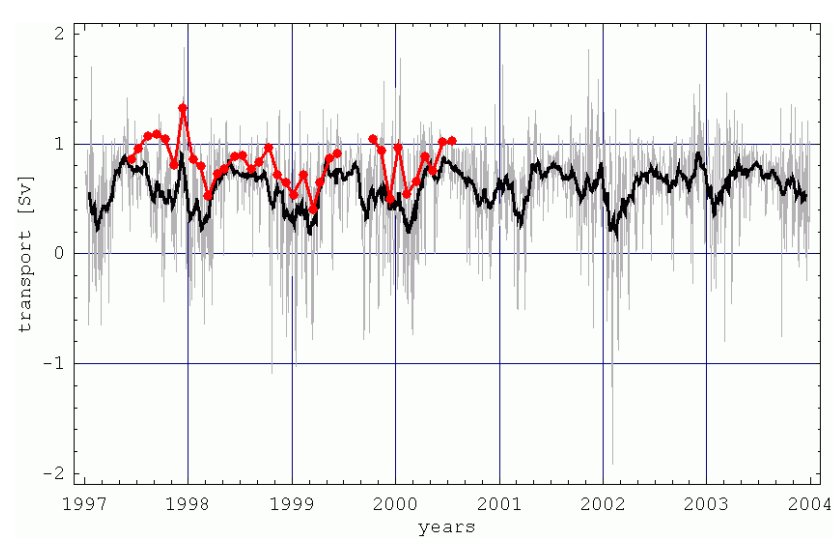

Fig. 7. Observed monthly mean AW volume flux through section 7 (red) compared to simulated total flux: daily means (grey), 31 day moving average (black). Positive values = eastward.

to the fact that the temperature evolution and volume flux are basically in phase, however, with a time lag of 4 months.

An explanation for the strong seasonal variability of the NIIC can be found in the wind forcing. The dependency of transport rates on local wind stress is apparent in a comparison of time series of the NCEP north component of the wind and the simulated northward NIIC transport. Figure 10 shows the wind stress from north at the position of maximum correlation with the NIIC (0.857) (cf. Fig. 19); the easterly wind component is slightly less correlated. Both curves show an almost identical behaviour which indicates that negative (southward) wind stress reduces or even blocks the 


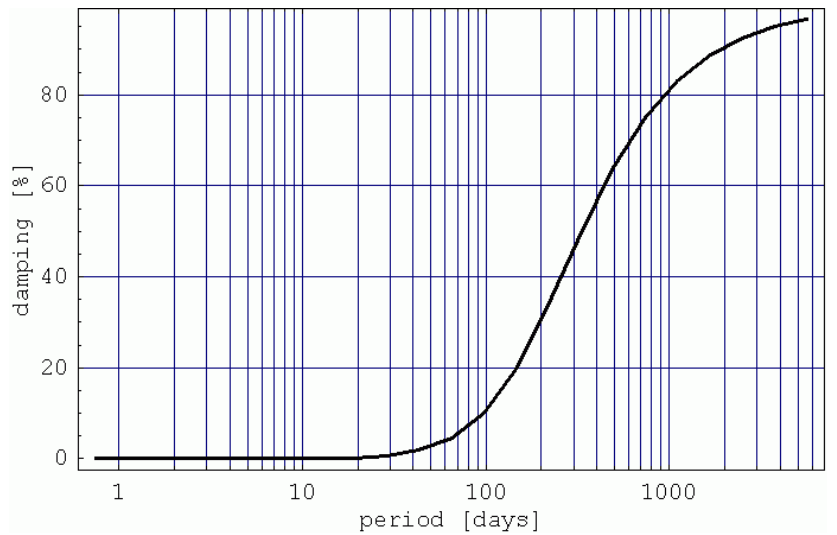

Fig. 8. Frequency dependent damping of temporal variability caused by the TS restoring with a time constant of 30 days.

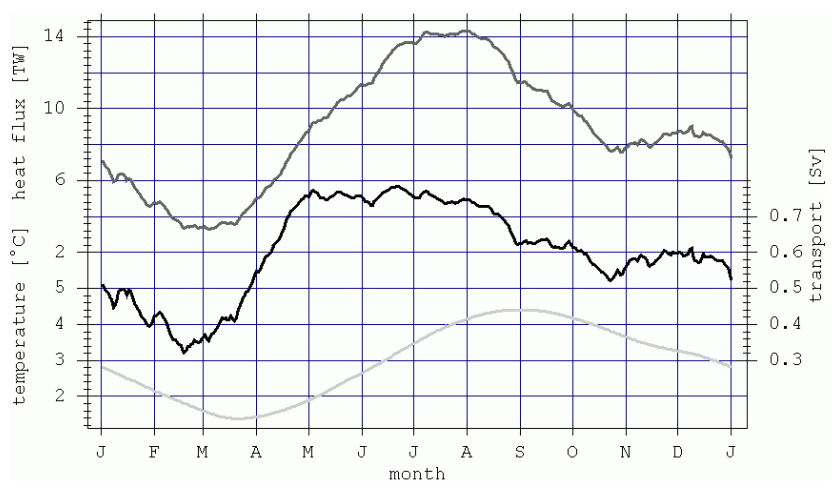

Fig. 9. Seasonal variability derived from the 1997-2003 simulation (31 days moving averages). Uppermost dark-grey curve: NIIC quasi-heat flux (relative to $0^{\circ} \mathrm{C}$ ) at section 7; black curve: NIIC volume flux normal to section 7; light-grey curve: spatially averaged water temperature over the North Icelandic shelf (area between section 7 and 12 with water depth below $300 \mathrm{~m}$ ).

NIIC. The rather abrupt reduction in southward wind stress in March/May down to the lower summer level is followed by a continuous increase from September to February. The NIIC responds directly to that wind signal and shows higher transport rates in particular during the summer months.

There is a distinct trend visible in Fig. 10 for the north component of the wind stress and also for the volume flux. During the period 1997 to 2003, decreasing southward winds caused an increase of the NIIC volume flux by $17 \%$ which results in a similar heat flux increase. However, large parts of this trend may just reflect the anomalous conditions during winter 2002/2003, which will be discussed in the next section.

\subsubsection{Interannual variability}

As outlined in the model description (cf. Sect. 2), a time constant of 30 days is used for the restoring of temperature and

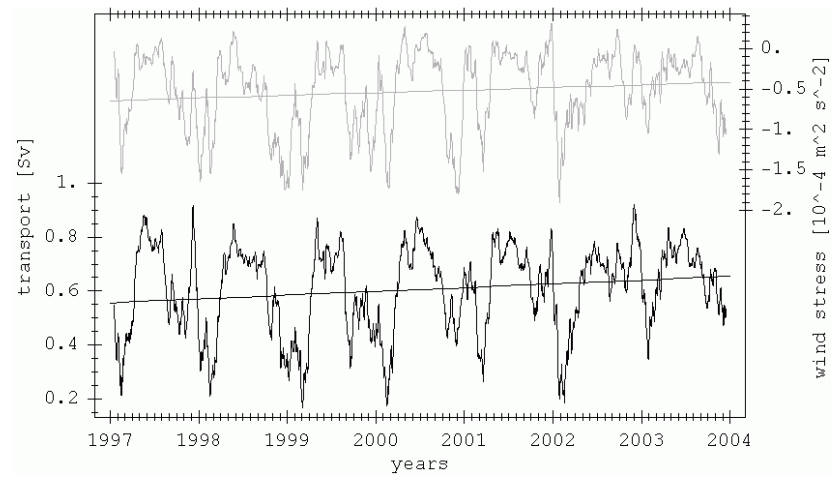

Fig. 10. 31 day moving averages of the southward wind stress component (NCEP) (divided by the water density of $1030 \mathrm{~kg} \mathrm{~m}^{-3}$ ) at $67^{\circ} 40^{\prime} \mathrm{N}, 22^{\circ} 32^{\prime} \mathrm{W}$ (upper curve) and simulated volume flux of the NIIC normal to section 7 (lower curve). Trends 1997-2003 are: $3.2 \times 10^{-6} \mathrm{~m}^{2} \mathrm{~s}^{-2}$ per year for the wind stress, and $0.014 \mathrm{~Sv}$ per year for the volume flux.

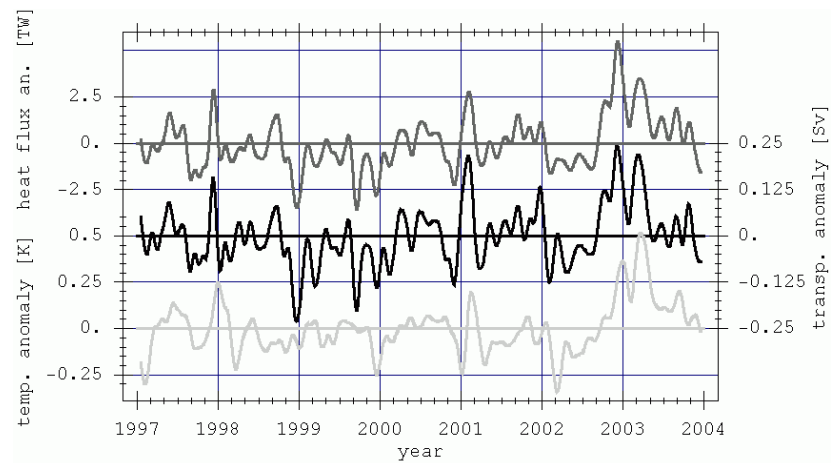

Fig. 11. Low-pass filtered (cut-off frequency: $(30 \text { days })^{-1}$ ) anomalies relating to the seasonal signals shown in Fig. 9. The uppermost, dark-grey curve shows simulated NIIC heat flux anomalies at section 7. The black curve in the middle shows the NIIC's volume flux anomalies normal to section 7. The light-grey curve below shows the spatially averaged water temperature anomaly over the North Icelandic shelf (area between sections 7 and 12 with water depth below $300 \mathrm{~m})$.

salinity data which inevitably damps variability on longer time scales ( $54 \%$ for a period of one year, $95 \%$ for 10 years; cf. Fig. 8). Nevertheless, the simulation shows distinct interannual signals, which can be interpreted as lower estimates.

A time series of NIIC transport anomalies together with temperature and heat flux anomalies (Fig. 11) reveals anomalous high volume fluxes during winter 1997/98, 2000/01 and 2002/03. These periods are also characterized by enhanced northward heat flux and positive temperature anomalies on the north Icelandic shelf. A particular clear anomaly occurred in winter 2002/03 when volume and temperature flux show positive anomalies of $40 \%$ and $60 \%$ respectively, leading to a simulated positive temperature anomaly over the North Icelandic shelf of $0.5 \mathrm{~K}$. At this location, the simulated 

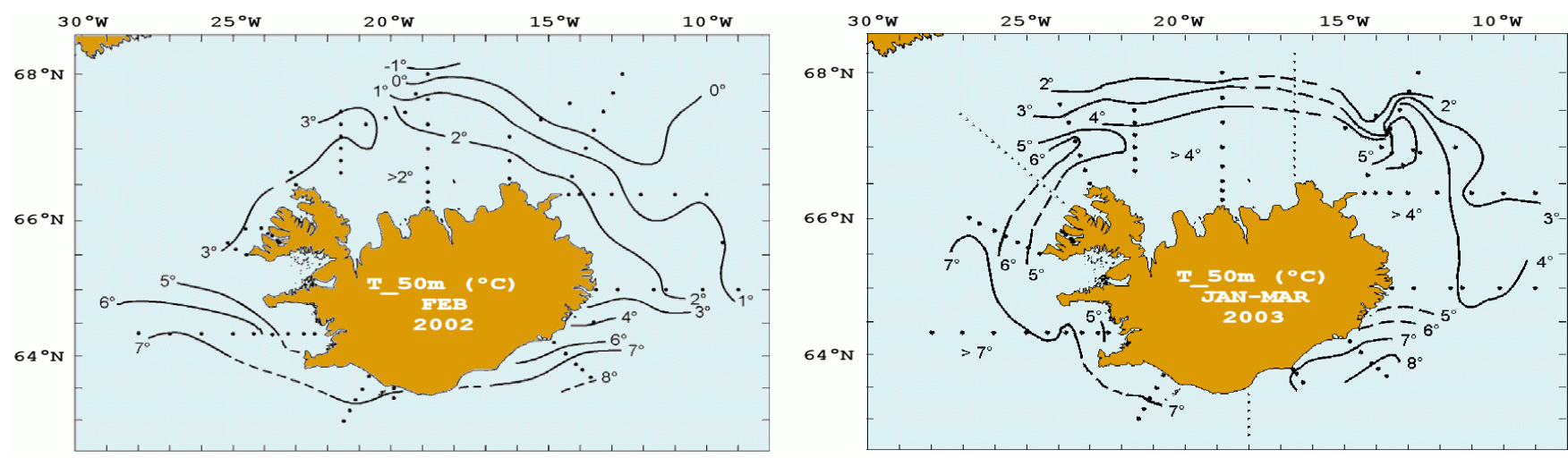

Fig. 12. Temperature measurements around Iceland at $50 \mathrm{~m}$ depth made in February 2002 (left) and January-March 2003 (right). (Modified after Gudmundsson, 2003, and Sigurjónsson, 2004).

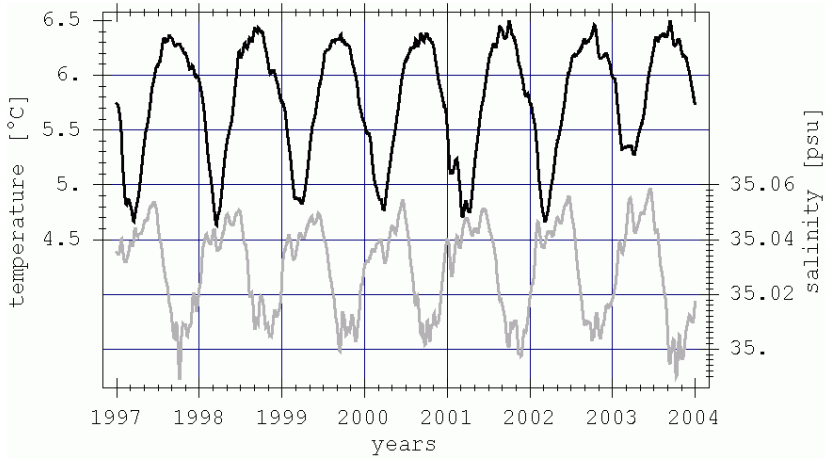

Fig. 13. Low-pass filtered (cut-off frequency: $\left(30\right.$ days) $\left.{ }^{-1}\right)$ simulated temperature (upper black curve) and salinity (lower grey curve) at section $3 \mathrm{~b}$ (mean between surface and $800 \mathrm{~m}$ depth) south of Denmark Strait.

difference between late winter temperatures in 2002 and 2003 is $0.8 \mathrm{~K}$. Temperature measurements from these years (Gudmundsson, 2003; Sigurjónsson, 2004) reveal an even higher difference of around $2 \mathrm{~K}$ in $50 \mathrm{~m}$ depth (Fig. 12), which probably confirms the anticipated inherent damping of simulated variability mentioned above. The anomaly is caused primarily by an unusual wind event that lasted for the whole winter season 2002/03: Instead of being blocked by strong southward wind stress, as usual during winter, the NIIC remained on a rather high level because of weak or missing winds from the north. This anomalous wind situation leads to an additional effect that even enhanced the 2002/03 event: Cooling and convection south of Iceland were weakened during winter 2002/03 due to missing advection of cold air masses from the north. As a result, the surface waters in the NIIC source region remain much warmer than in previous years (Fig. 13). The 2002/03 anomaly is thus a combined effect of i) enhanced northward advection of ii) unusual warm waters towards the north Icelandic shelf.
Although there seems to be a strong link between heat flux and mean temperature on the north Icelandic shelf, negative volume flux anomalies like during winter 1998/99 do not necessarily cause negative temperature anomalies north of Iceland. Whereas volume and heat flux are obviously well correlated, the comparison between heat flux and temperature anomaly gives a correlation of only 0.75 , based on a time lag of 17 days. This means that roughly $56 \%$ of the temperature evolution on the north Icelandic shelf can be explained by heat advection through the NIIC. The remaining $43 \%$ are determined by other processes such as the entrainment rate of PW from the north or local atmospheric heat exchange. However, with respect to a possible underestimation of simulated NIIC volume and heat fluxes, the $56 \%$ contribution of the NIIC to the temperature evolution on the north Icelandic shelf should be seen as a lower estimate.

3.4 Origins, pathways and composition of NIIC waters: a tracer study

The analysis of the simulated flow fields suggest, that the NIIC is composed of an in-shore branch crossing the southwest Icelandic shelf and an off-shore branch in deep waters, mainly fed by AW from the Irminger Current. Both sources merge into Denmark Strait where the NIIC collides with the East Greenland Current flowing in opposite direction. In the frontal zone, some parts of the NIIC re-circulate, other parts continue northward, mixing with PW. In order to define the upstream pathways and origins of the NIIC, a tracer dispersion simulation based on the 1997-2003 mean flow field is performed.

The focus is on model section 7 , where a volume of $2.5 \times 10^{11} \mathrm{~m}^{3}$ of NIIC-water is marked with passive tracers. These tracers are advected backward in time and the tracer flux through different sections is integrated over three years. The model results are depicted in Fig. 14. Vectors show the vertically integrated tracer flux over 3 years, originating from 
the marked volume in section 7 (i.e. the white line denoting $100 \%$ ), following the integral $I$ :

$I=\int_{t=0}^{t=3} \int_{z=-D}^{z=\zeta} c \boldsymbol{v} d z d t$

where $c$ denotes the dimensionless tracer concentration and $v$ the current vector. The vectors have the unit $\left[\mathrm{m}^{2}\right]$. At the white sections, the percentage of the initial volume is given, which has passed these lines during three years of calculation.

The simulation shows a surprising high amount of PW (57\%) that is entrained into the NIIC. Only $43 \%$ originates from south of Denmark Strait, consisting of approx. 29\% AW from the Irminger Current (i.e. the off-shore branch) and $14 \%$ waters from the south Icelandic shelf (i.e. the in-shore branch).

The NIIC's main southern path has its origin in the Iceland basin, leads westward along the Iceland-Scotland ridge and continues along the south Icelandic continental slope. After separation of the in-shore branch, the main path turns to the south, follows the Reykjanes Ridge for around $300 \mathrm{~km}$ before crossing the ridge to join the Irminger Current towards Denmark Strait.

Vertical profiles along the source pathways of the NIIC (Fig. 15) show that the entrained PW originates from the upper $200 \mathrm{~m}$ of the East Greenland Current (profile 15 a) whereas the AW from south of Denmark Strait is more evenly distributed over the whole depth range between $0-1000 \mathrm{~m}$ (profile $15 \mathrm{~g}$ and $\mathrm{h}$ ). The in-shore branch (profile $15 \mathrm{~d}$ ) contributes to the NIIC with high concentrations at the surface whereas the off-shore branch (profile $15 \mathrm{c}$ ) reveals a bi-modal structure with high concentrations at the surface and in $150 \mathrm{~m}$ depth. The core of the NIIC close to section 7 is located in $100 \mathrm{~m}$ depth (profile $15 \mathrm{~b}$ ).

A remarkable feature is the vertical structure at the far upstream profile $15 \mathrm{~h}$, where tracers are concentrated in depths between 400 and $600 \mathrm{~m}$. The source for water masses at that position and in those depths is most likely the overflow coming across the Iceland-Faeroe ridge or through the FaeroeShetland channel. Compared to profile $15 \mathrm{e}, \mathrm{g}$ and $\mathrm{h}$, profile $15 \mathrm{f}$ shows the shallowest core location south of Iceland, in less than $100 \mathrm{~m}$ depth. Obviously the NIIC pathways also have a distinct vertical component. The reason for this could be the frequently observed upwelling at the continental slope along the south coast.

Based on time series of the NIIC through-flow from 19972003 (cf. Sect. 3.3.2), we determined two one-year periods, one with maximum transport rates (8 September 20029 September 2003, NIIC at section $7=0.7 \mathrm{~Sv}$ ) and one with minimum transport rates (15 October 1998-14 October 1999, NIIC at section $7=0.5 \mathrm{~Sv}$ ). Extracted flow fields were used to repeat the tracer experiment for these two periods. The comparison shows, that with increasing NIIC volume

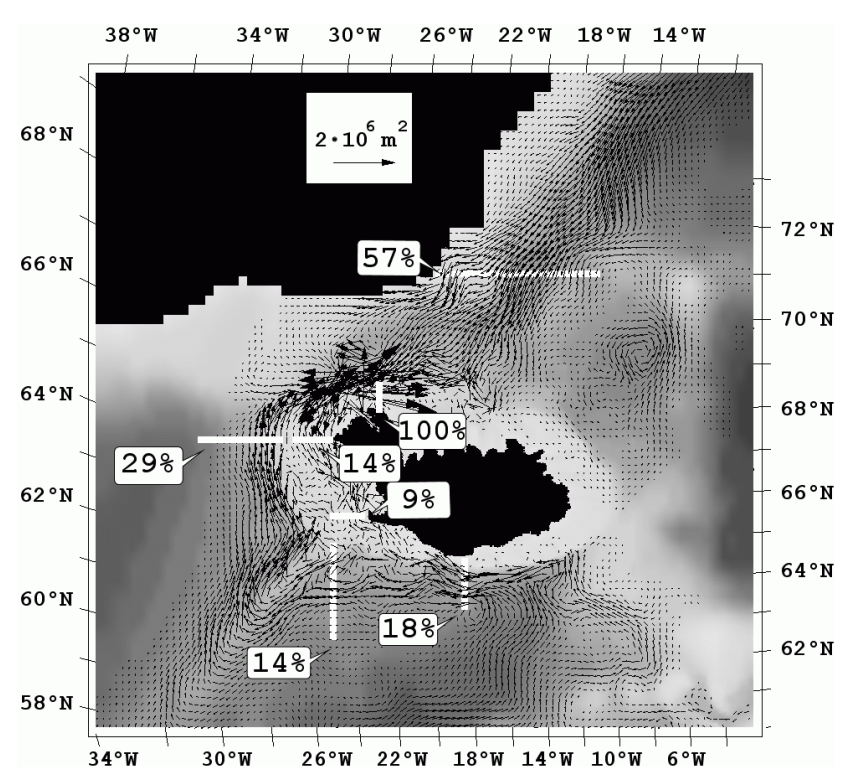

Fig. 14. Origins, pathways and composition of NIIC water masses. Vectors show the vertically integrated tracer flux over three years. The percentage values refer to the white sections and indicate the fraction of the initial volume (100\%) that passed these sections during three years. The greyscale illustrates topography.

transport the fraction of AW rises simultaneously (Fig. 16), during the $2002 / 03$ period up to $46 \%$. However, the intensification of AW inflow in 2002/03 is mainly through the offshore branch. The in-shore branch fraction at section 1 even decreases in that period from $10 \%$ (1998/99) down to $8 \%$, leading to nearly unchanged volume flux between 0.05 and $0.06 \mathrm{~Sv}$ of water which later passes section 7 .

\section{Discussion}

The simulated spatial variability of the NIIC is characterized by a steady along-stream weakening of volume and heat transport within south-west Denmark Strait followed by an amplification further north. Two reasons are responsible for that feature: a) the re-circulation of AW in Denmark Strait and b) the entrainment of PW along the front in Denmark Strait and further downstream, in the north-western waters.

Based on the simulated volume and heat fluxes and on the dispersion patterns of the tracer study in Sect. 3.4, Fig. 17 presents a schematic sketch of NIIC pathways and transport rates. The separation of the NIIC from the Irminger Current occurs mainly between section 3 and 4. Approximately $90 \%$ of the AW re-circulate here and only $10 \%$ of the Irminger Current contribute to the NIIC. If we assume that the in-shore branch feeds completely into the NIIC, we can state that this pathway contributes approx. $0.2 \mathrm{~Sv}$ whereas the off-shore branch contributes $0.7 \mathrm{~Sv}$ to the total volume flux through section 4 (0.9 Sv). 

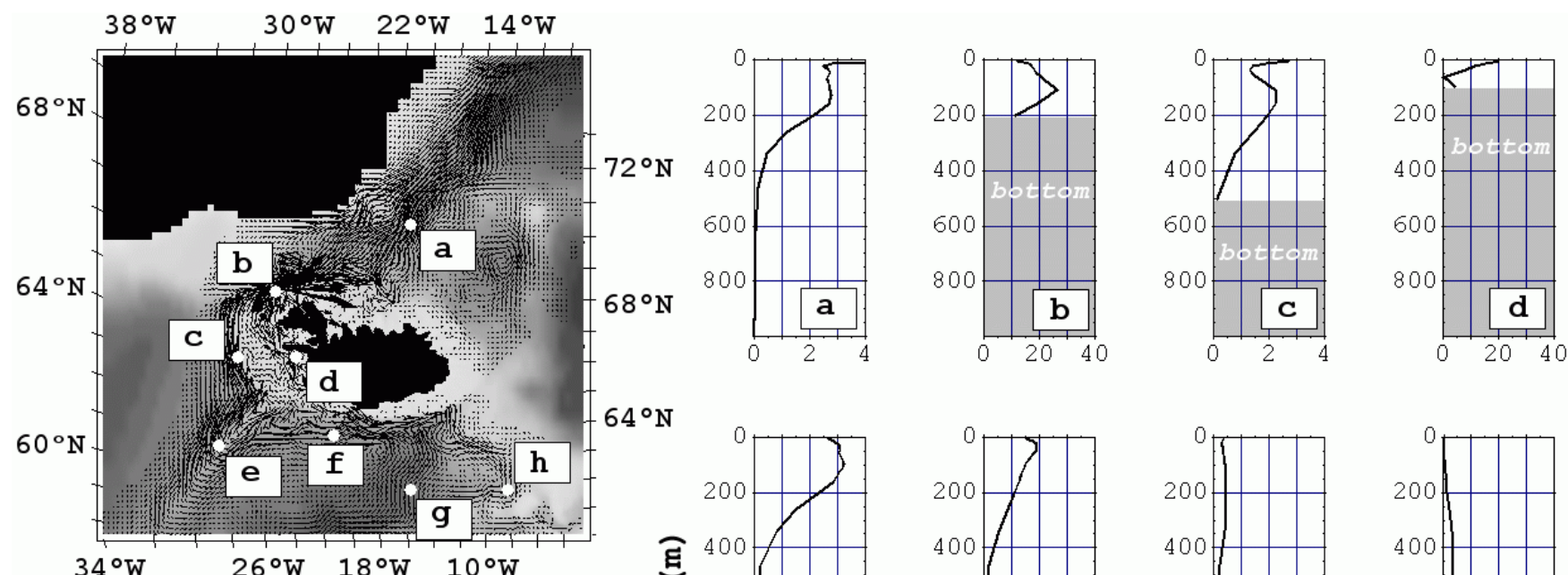

$64^{\circ} \mathrm{N}$
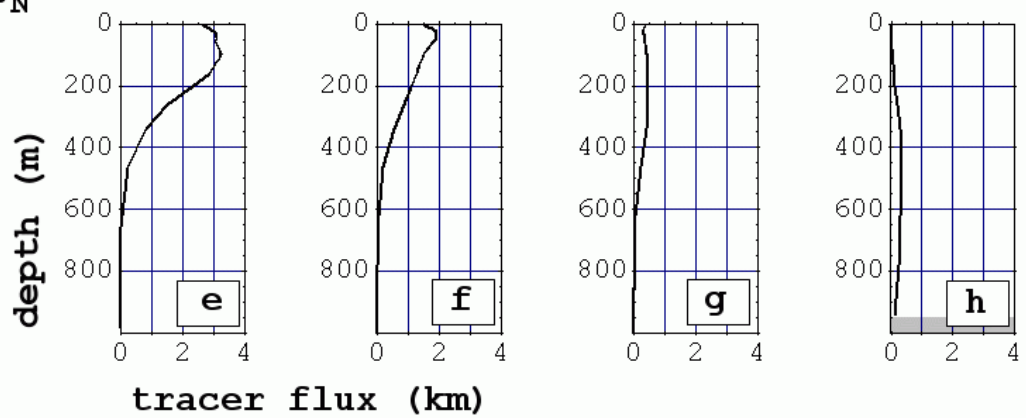

Fig. 15. Vertical profiles of NIIC tracer flux (cf. Fig. 14) integrated over three years. Letters refer to the profile position. Note the higher range for profile $b$ and $d$.
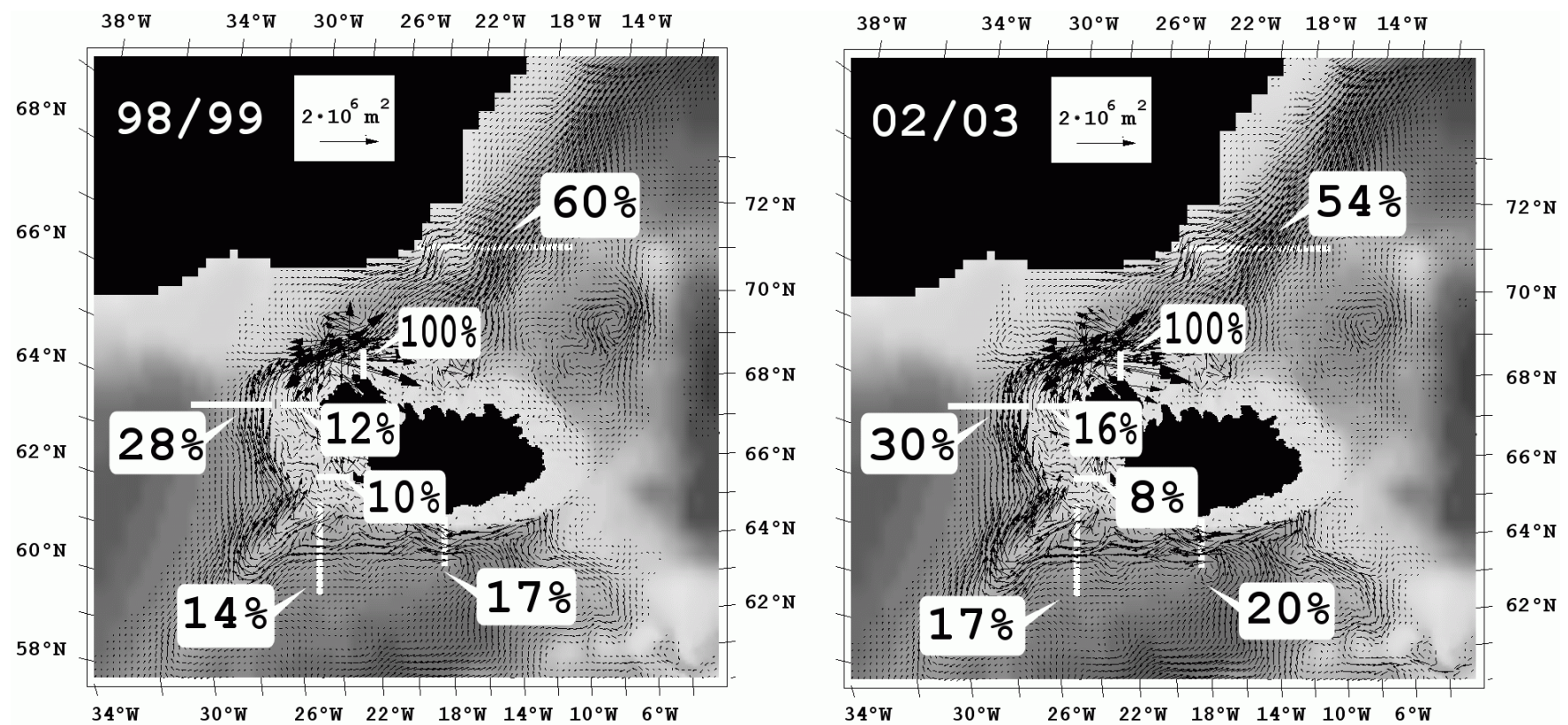

Fig. 16. Origins, pathways and composition of NIIC water masses. Repeated simulation of the NIIC tracer dispersion (cf. Fig. 14) on the basis of two different current fields. Left: Mean current field October 1998-1999 (weak NIIC=0.5 Sv at section 7). Right: Mean current field September 2002-2003 (strong NIIC=0.7 Sv at section 7).

A further reduction of the NIIC due to re-circulating AW occurs between section 4 and 5 , where in particular the volume flux drops from 0.9 to $0.4 \mathrm{~Sv}$. But also the heat flux is reduced from $18 \mathrm{TW}$ down to $7 \mathrm{TW}$, the mean salinity falls from 34.88 down to 34.72 and the mean temperature drops by half a degree (cf. Table 2). The reduction in volume and heat transport suggests a further re-circulation of AW in the range of $0.6 \mathrm{~Sv}$ whereas the drop in mean salinity can only be 


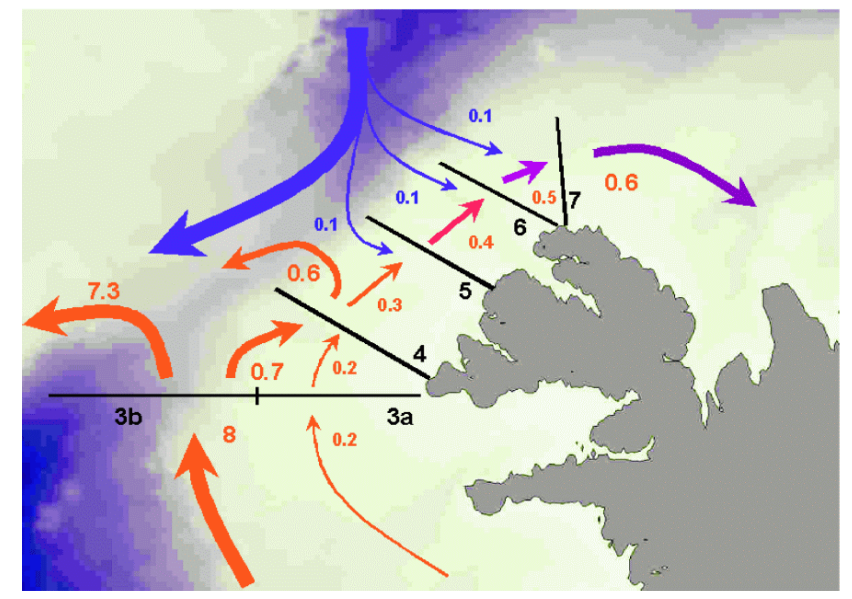

Fig. 17. Sketch of the NIIC pathway and volume flux based on the simulated 1997-2003 mean flow field. Red AW contribution, blue PW contribution. Black numbers denote sections, coloured numbers are Sverdrup rates. Note that the $0.3 \mathrm{~Sv}$ AW continuing north beyond section 4 are, according to our tracer studies, composed of $2 / 3$ off-shore branch and 1/3 in-shore branch water (2:1 ratio), and that both branches are significantly reduced due to re-circulation to the west.

explained by entrainment of PW which should be in a range of $0.1 \mathrm{~Sv}$.

On the following sections 6 and 7, transport and heat flux remain stable (it even recover slightly) but the mean temperature and salinity continues to fall. To meet these constrains, further entrainment of PW is needed. The total transport through section $7(0.6 \mathrm{~Sv})$ is finally made up of roughly $0.3 \mathrm{~Sv} \mathrm{PW}$ and $0.3 \mathrm{~Sv}$ AW which would be consistent with the results of the tracer study ( $47 \%$ AW versus $53 \% \mathrm{PW}$ ).

Although this sketch gives a rather comprehensive view of the NIIC pathway, we clearly see discrepancies between model results and observations. In contrast to our model findings, Jónsson and Valdimarsson (2005) estimate from observations that $66 \%$ AW (south of Denmark Strait) and only $34 \%$ PW (north of Denmark Strait) contributes to the Hornbanki through-flow (i.e. section 7). There are also indications that simulated mean salinity and temperatures are too cold and too fresh compared to observations. We therefore argue that the simulated low AW amount and the strong entrainment of PW in the model leads to a rapid fading of the NIIC signal that is connected with too low salinity, temperature and heat flux rates. This also explains why the values of modelled and observed inflowing AW given in Table 1 disagree for the Greenland - Iceland passage. A further indication for an overestimated fading of the simulated NIIC signal is the fact that model section $4(0.9 \mathrm{~Sv} \mathrm{AW}, 18 \mathrm{TW})$ agrees well with the Hornbanki observations at section $7(0.75 \mathrm{~Sv}$ AW, 18.9 TW) although model section 4 is much more upstream than Hornbanki.

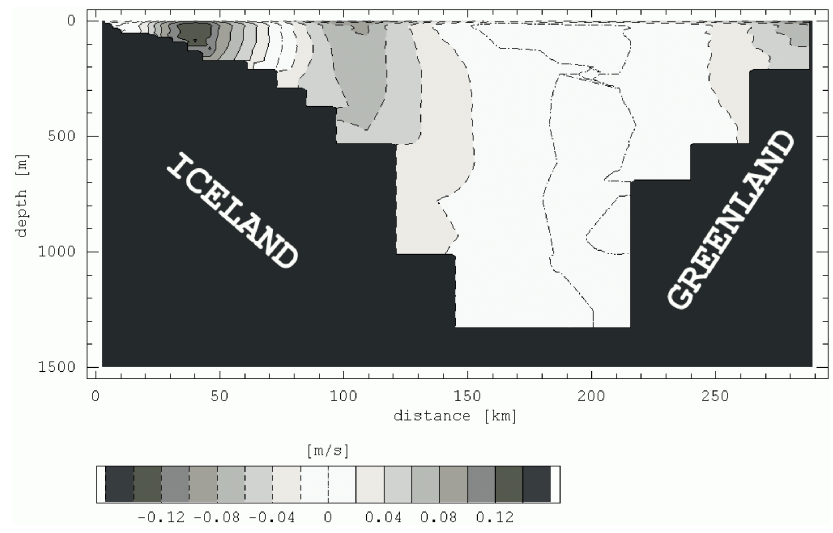

Fig. 18. Cross-section flow in Denmark Strait (white line in Fig. 5). Negative (positive) values indicate south-westward (northeastward) flow.

Reasons for an overestimated weakening of the NIIC signal can be manifold. It can be speculated that even the high resolution of less than $5 \mathrm{~km}$ on the Icelandic shelf is still too coarse to capture the entrainment processes along the fronts between AW and PW. But a more likely candidate is the parameterisation of horizontal turbulent exchange coefficients, i.e. the Smagorinsky constant of 0.7. The value might be still too high, although this parameter was optimised in a validation exercise that compared intensively model trajectories in this area with observed buoy drifts (Valdimarsson and Malmberg, 1999). However, model runs with smaller Smagorinsky constants showed higher NIIC volume fluxes.

The underestimation of NIIC inflow of AW is a common problem in many model studies (e.g. Karcher et al., 2003; Nilsen et al., 2003; Drange et al., 2005; Griffies et al., 2005; Oka and Hasumi, 2006) mainly because of too coarse resolution in model grid and forcing data. Although there are still some discrepancies, the present application is the highest resolving model of that area which is able to reproduce a fairly well established NIIC. This allows a closer look especially on driving mechanisms of the NIIC.

A vertical section north of Denmark Strait shows, that just above the shelf break of west Iceland, the southward flowing branch of the East Greenland Current forms a distinct front to the northward flowing NIIC (Fig. 18). The NIIC is pushed onto the Icelandic shelf which means that deeper parts of the AW inflow are cut off and have to re-circulate southward without entering Denmark Strait. If the southward flowing East Greenland Current gets even stronger and broadens, the Denmark Strait through-flow of AW could be totally blocked or suppressed. The northward flowing NIIC would then be mainly controlled by the strength of the southward flowing East Greenland Current.

Further model analysis revealed, that the main forcing for this control mechanism is the local wind field. The comparison between NIIC transport rates and daily mean wind fields 

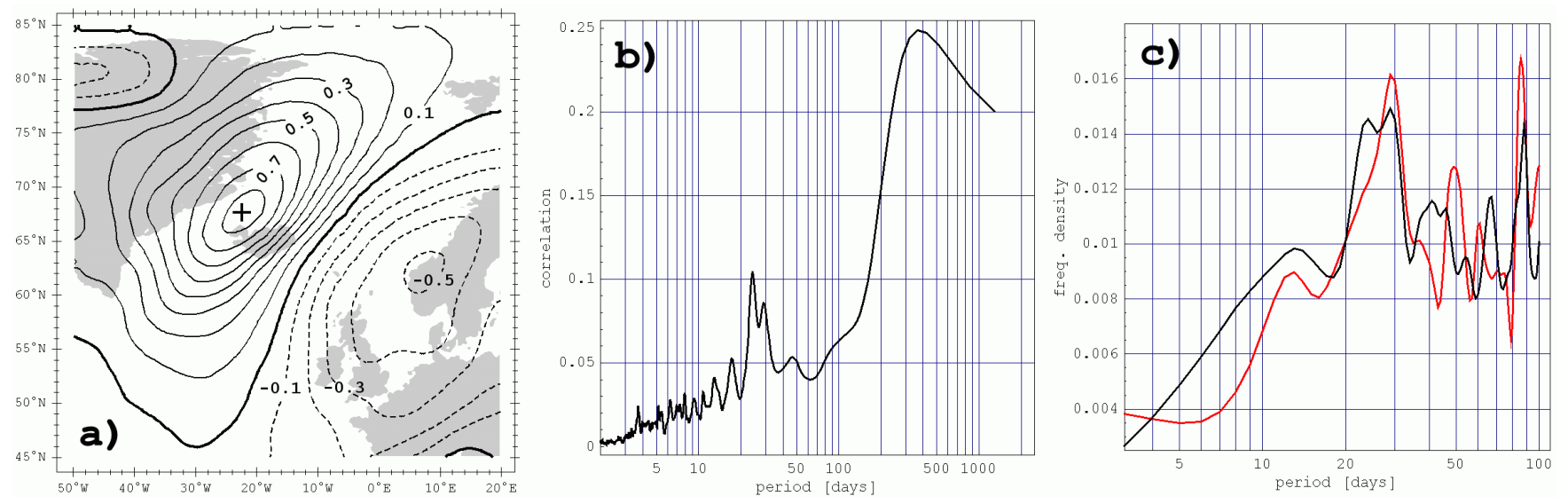

Fig. 19. (a) Correlation coefficients between the north component of the daily mean wind stress and the volume flux of the NIIC, normal to section 7. The maximum coefficient is 0.857 , north-west of Iceland at $67^{\circ} 40^{\prime} \mathrm{N}, 22^{\circ} 32^{\prime} \mathrm{W}(+)$. (b) The cross spectrum of the correlation between both time series at this position. Highest correlation is found at a period of a year (seasonal cycle), other maxima at periods of 24 and 29 days. (c) The normalised frequency spectra of both time series, black: NIIC, red: wind stress.

shows a maximum correlation of 0.86 between the north component of the wind-stress at $67^{\circ} 40^{\prime} \mathrm{N}, 22^{\circ} 32^{\prime} \mathrm{W}$ and the volume flux through section 7 (Fig. 19a). This good correlation indicates that the NIIC transport is significantly reduced if southward winds enforce the East Greenland Current. In order to analyse at which frequencies this driving mechanism is most efficient, a cross spectral analysis and normalized frequency spectra for NIIC volume flux and north-south wind stress were computed. Apart from high values for long periods ( $>300$ days), the cross spectrum of both time series (Fig. 19b) shows two distinct peaks for periods of 24 and 29 days. This suggests that the seasonal and the 20-30 days variability of the NIIC are mainly controlled by the atmosphere, i.e. the wind stress. The frequency spectrum of the southward wind stress (Fig. 19c, red curve) shows a distinct maximum for periods between 20 and 30 days, which reflects the oscillation between two large scale weather conditions: Low pressure west of Iceland associated with weak (or reversed) southward wind stress and strong NIIC, and low pressure east of Iceland with strong southward wind stress and weak (or reversed) NIIC. The similarity to the NIIC frequency spectrum (Fig. 19c, black curve) suggests that on these periods the NIIC responds very sensitively to the variability of the north-south wind stress.

Two further points have to be mentioned in this context: a) the spatial resolution of the NCEP forcing data is, as already mentioned, rather coarse and $b$ ) the analysis of volume flux versus wind stress is based on daily mean values. High frequent and small scale features like e.g. fast moving polar lows are thus insufficiently resolved. The synoptic scale between one and three days (i.e. the storm frequency) might therefore be underestimated in the spectral analysis.

The dispersion model results in terms of origin, pathways and composition of NIIC tracers have important implications for the assessment of cod egg drift, the main motivation for this model study. Since the south Icelandic shelf is the main spawning area for cod, the drift of spawned eggs depend mostly on the intensity of the in-shore coastal flow which has only a small share in the NIIC composition. Even more important in this respect is the fact that the in-shore branch shows a different behaviour than the Irminger Current and NIIC signals: during years with high NIIC transport rates, the tracer contribution from the off-shore Irminger Current increased equivalently whereas the in-shore contribution remained nearly unchanged. This means that the NIIC transport observed north of Iceland does not necessarily reflect the intensity of cod egg drift around Iceland and hence the strength of year classes appearing in the north.

\section{Conclusions}

The ocean model CODE produces circulation patterns which are in good agreement with the general view of the currents around Iceland. Based on detailed analysis of fluxes of volume, heat and passive tracers, the paper presents a comprehensive and coherent view of the origins, pathways and composition of NIIC water masses. The comparison between simulation and observational-based time series points to a possible underestimation of the simulated NIIC volume flux of probably up to $50 \%$. Concerning the ratio of AW and PW in the NIIC, the model also shows some discrepancies with observations. Whereas the simulation suggests an almost equivalent AW/PW ratio (0.43/0.57), Jónsson and Valdimarsson (2005) give a AW/PW ratio of approx. 0.66/0.34. These discrepancies could be caused by an overestimated momentum, salt and heat diffusion around Iceland within the simulation. 
Despite obvious differences in the composition of the NIIC, the model allows to determine the origin of NIIC water masses coming from the south (i.e. the AW composition). Two sources could be found: the Irminger Current flowing off-shore in deep water along the Reykjanes Ridge and the in-shore coastal component, flowing on the south Icelandic shelf. The main source for AW in the NIIC is the off-shore Irminger Current as part of the sub-polar gyre (66\%). South Icelandic shelf waters contribute only $33 \%$ to the AW composition of the NIIC which implies that the ratio between Irminger Current and the coastal component is 2:1. Given the AW/PW ratio of Jónsson and Valdimarsson (2005) and our ratio for the $\mathrm{AW}$ composition we can estimate the fractions of the NIIC components as follows: $34 \%$ PW from the East Greenland Current, 45\% AW from the Irminger Current and $21 \%$ south Icelandic shelf water.

The seasonal variability of the NIIC is considerable and mainly influenced by local north-south wind stress. Highest transport rates occur in summer when winds from the north are weak. The increase of volume transport falls together with the surface temperature increase due to atmospheric and solar warming. Both processes lead to a more than three times higher heat flux rate in summer than in winter. Significant variability was also simulated on the interannual scale. In particular the winter 2002/2003 showed anomalous high transport and heat flux rates, which caused a positive temperature anomaly over the north Icelandic shelf of around $0.5 \mathrm{~K}$ within the simulation. Observations indicate that this anomaly was partly even higher, up to $1 \mathrm{~K}$.

The drift of cod eggs, which is the main motivation for this model study, depends very much on the in-shore flow across south-west Icelandic waters since the major spawning areas are located here (Storr-Paulsen et al., 2004; Brickman et al., 2006). The model indicates so far that the in-shore branch is to a certain extent uncoupled from the large scale Irminger Current which presents the major source for the NIIC. Linking the intensity of cod egg drift or even the strength of year classes to NIIC or Irminger Current indices might thus be very critical and lead to wrong assumptions. Beside reducing the diffusion to more realistic values, future modelling of egg drift around Iceland has to resolve the time and space variability of the coastal flow on the shelf which requires eddy resolving models forced with high resolution atmospheric data. The present model is eddy resolving on most of the Icelandic shelf but the general lack of high quality forcing data inhibits so far a more detailed study of the coastal flow. This problem could be solved by including a high resolution atmosphere model in numerical studies of the NIIC.

Acknowledgements. The model development and analyses have been supported by EU-project METACOD (Q5RS-2001-00953). The authors would like to thank H. Valdimarsson and S. Jónsson for providing the mooring and surface drifter data. Thanks also to J. Mortensen, D. Brickman and three anonymous referees for their helpful comments.
Edited by: K. J. Heywood

\section{References}

van Aken, H. M. and Becker, G.: Hydrography and through-flow in the north-eastern North Atlantic Ocean: the Nansen project, Progress in Oceanography, 38, 297-346, 1996.

Backhaus, J. O.: A three-dimensional model for the simulation of shelf sea dynamics, Deutsche hydrographische Zeitschrift 38, 165-187, 1985.

Bamber, J., Muller, J. P., and Mandanayake, A.: A Global 5 Arc Minute Digital Elevation Model Derived from the Geodetic Phase of ERS-1. Proc. 3rd ERS Symp. On space of the service of our environment, Florenz, March 1997, 1997.

Bersch, M.: On the circulation of the north-eastern North Atlantic, Deep Sea Res., 42, 1583-1607, 1995.

Brickman, D., Marteinsdottir, G., Logemann, K., and Harms, I.: Drift Probabilities for Icelandic Cod Larvae, ICES JMR, accepted, 2006.

Dietrich, G., Kalle, K., Krauss, W., and Siedler, G.: General Oceanography, 2nd ed., John Wiley and Sons, New York, 626 pp, 1975.

Drange, H., Gerdes, R., Gao, Y., Karcher, M., Kauker, F., and Bentsen, M.: Ocean General Circulation Modelling of the Nordic Seas, in: The Nordic Seas: An Integrated Perspective (Drange, Dokken, Furevik, Gerdes and Berger, Eds.), AGU Monograph 158, American Geophysical Union, Washington D.C., pp. 199220, 2005.

Griffies, S. M., Gnanadesikan, A., Dixon, K. W., Dunne, J. P., Gerdes, R., Harrison, M. J., Rosati, A., Russell, J. L., Samuels, B. L., Spelman, M. J., Winton, M., and Zhang, R.: Formulation of an ocean model for global climate simulations, Ocean Sci., 1, 45-79, 2005, http://www.ocean-sci.net/1/45/2005/.

Gudmundsson, K.: thættir úr vistfrædi sjávar 2001 og 2002. Environmental conditions in Icelandic waters in 2001 and 2002, Report of the Marine Research Institute, Reykjavik, Iceland, No. 96, 37 pp, 2003.

Hansen, B. and Østerhus, S.: North Atlantic-Nordic Seas exchanges, Progress in Oceanography, 45, 109-208, 2000.

Harms, I. H., Backhaus, J. O., and Hainbucher, D.: Modelling the seasonal variability of circulation and hydrography in the Iceland-Faeroe-Shetland overflow area, ICES CM 1999/L:10, Annual Science Conference, 29 September to 2 October 1999 , Stockholm, Sweden, 1999a.

Harms, I. H., Backhaus, J. O., and Hainbucher, D.: The circulation in the EU-TASC-region during the Calanus year 1996/1997 ICES CM 1999/L:33, Annual Science Conference, 29 September to 2 October 1999, Stockholm, Sweden, 1999b.

Harms, I. H., Heath, M., Bryant, A., Backhaus, J. O., and Hainbucher, D.: Modeling the northeast Atlantic circulation - Implications for the spring invasion of shelf regions by Calanus finmarchicus ICES-Journal of Marine Science, vol. 57, no. 6, also issued as: ICES Marine Science Symposia, vol. 212 "Population Dynamics of Calanus in the North Atlantic", 24-27 August 1999, Tromsø, Norway, 2000.

Harms, I. H., Hübner, U., Backhaus, J. O., Kulakov, M., Stanovoy, V., Stepanets, O., Kodina, L., and Schlitzer, R.: Salt intrusions in 
Siberian river estuaries: Observations and model experiments in $\mathrm{Ob}$ and Yensiei, in: Siberian river runoff in the Kara Sea: Characterisation, quantification, variability and environmental significance, edited by: Stein, R., Fahl, K., Fütterer, D. K., Galimov, E. M., and Stepanets, O. V., Proceedings in Marine Science, vol. 6, Elsevier Amsterdam 2003, ISBN 0-444-51365-5, 484 pp, 2003.

Jakobsen, P. K., Ribergaard, M. H., Quadfasel, D., Schmith, T., and Hughes, C. W.: The near surface circulation in the Northern North Atlantic as inferred from Lagrangian drifters: variability from the mesoscale to interannual, J. Geophys. Res., 108(C8), 3251, doi:10.1029/2002JC001554, 2003.

Jakobsson, M., Cherkis, N., Woodward, J., Coakley, B., and Macnab, R.: A new grid of Arctic bathymetry: A significant resource for scientists and mapmakers, EOS Transactions, American Geophysical Union, 81(9), p. 89, 93, 96, 2000.

Jónsson, S. and Briem, J.: Flow of Atlantic Water west of Iceland and onto the north Icelandic Shelf, ICES Marine Science Symposia, 219, 326-328, 2003.

Jónsson, S. and Valdimarsson, H.: The flow of Atlantic water to the North Icelandic Shelf and its relation to the drift of cod larvae, ICES J. Mar. Sci., 62(7), 1350-1359, 2005.

Kalnay, E., Kanamitsu, M., Kistler, R., Collins, W., Deaven, D., Gandin, L., Iredell, M., Saha, S., White, G., Woollen, J., Zhu, J., Chelliah, M., Ebisuzaki, W., Higgins, W., Janowiak, J., Mo, K., Ropelewski, C., Wang, J., Leetmaa, A., Reynolds, R., Jenne, R., and Joseph, D.: The NCEP/NCAR 40-year reanalysis project, Bull. Am. Meteorol. Soc., 77, 437-471, 1996.

Karcher, M. J., Gerdes, R., Kauker, F., and Köberle, C.: Arctic warming: Evolution and spreading of the 1990s warm event in the Nordic Seas and the Arctic Ocean, J. Geophys. Res., 108(C2), 3034, doi:10.1029/2001JC001265, 2003.

Khokhlov, A. M.: Fully threaded tree algorithms for adaptive refinement fluid dynamics simulations, J. Comp. Phys., 143(2), 519543, 1998.

Kochergin, V. P.: Three-dimensional prognostic models, in: Threedimensional coastal ocean models, edited by: Heaps, N. S., Coastal and Estuarine Sciences, 4, 201-208, 1987.

Kristmannsson, S. S., Malmberg, S. A., and Briem, J.: Inflow of warm Atlantic water to the subarctic Iceland Sea, Rapports et Procès-Verbaux des Réunions du Conseil International pour l'Exploration de la Mer, 188, 74, 1989.

Kristmannsson, S. S.: Flow of Atlantic Water into the northern Icelandic shelf area, 1985-1989, ICES Cooperative Research Report, 225, 124-135, 1998.

Logemann, K., Backhaus, J. O., and Harms, I. H.: SNAC: a statistical emulator of the north-east Atlantic circulation, Ocean Modelling, 7(1-2), 97-110, 2004.
Logemann, K.: Modelluntersuchung zur Erwärmung des Bodenwassers der Grönlandsee, Ph.D. thesis, University of Hamburg, 182 pp, 2006.

Millero, F. J., Chen, C.-T., Bradshaw, A., and Schleicher, K.: A New High Pressure Equation of State for Seawater, Deep Sea Res., 27, 255-264, 1980.

National Energy Authority, Hydrological Service: Hydrological Service Database, service nr 2003/33, Reykjavik, Iceland, 2003.

Nilsen, J. E. Ø., Gao, Y., Drange, H., Furevik, T., and Bentsen, M.: Simulated North Atlantic-Nordic Seas water mass exchange in an isopycnic coordinate OGCM, Geophys. Res. Lett., 30(10), 1536, doi:10.1029/2002GL016597, 2003.

Oka, A. and Hasumi, H.: Effects of model resolution on salt transport through northern high- latitude passages and Atlantic meridional overturning circulation, Ocean Modelling, 13(2), 126-147, 2006.

Popinet, S.: Gerris: a tree-based adaptive solver for the incompressible Euler equations in complex geometries, J. Comp. Phys., 190, 572-600, 2003.

Röske, F.: A global heat and fresh water forcing data set for ocean models, Ocean Modelling, 11, 235-297, 2006.

Sigurjónsson, J.: thættir úr vistfrædi sjávar 2003. Environmental conditions in Icelandic waters 2003. Report of the Marine Research Institute, Reykjavik, Iceland, No. 101, 43 pp, 2004.

Smagorinsky, J.: General Circulation Experiments with the Primitive Equations. I. The Basic Experiment, Mon. Wea. Rev., 91(3), 99-106, 1963.

Steele, M., Morley, R., and Ermold, W.: PHC: A global ocean hydrography with a high quality Arctic Ocean, J. Climate, 14, 2079-2087, 2001.

Stefánsson, U.: North Icelandic Waters. Rit Fiskideildar, 3, 269 pp, 1962.

Storr-Paulsen, M., Harms, I., Logemann, K., Wieland, K., and Rätz, H.-J.: The impact of environmental conditions on distribution, transport and migration for cod (Gadus morhua) in East and West Greenland waters ICES Symposium on "The Influence of Climate Change on North Atlantic Fish stocks", Bergen, Norway, 2004

Valdimarsson, H. and Malmberg, S. A.: Near-surface circulation in Icelandic waters derived from satellite tracked drifters, Rit Fiskideildar 16, 23-39, 1999.

van Leer, B.: Towards the Ultimate Conservative Difference Scheme. V: A Second Order Sequel to Godunov's Method, J. Comput. Phys., 32, 101-136, 1979.

Worthington, L. V.: The Norwegian Sea as a Mediterranean Basin, Deep-Sea Res., 17, 77-84, 1970. 